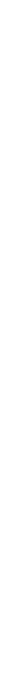

Heritage and Artistic Boon: Valuing Prizren Castle

Authors: $\quad$ Bujar Q. Bajçinovci, Kaltrina Thaçi

Submitted:

13. September 2016

Published:

13. September 2016

Volume:

3

Issue: 5

Keywords: $\quad$ Humanities, Art, Prizren Castle, Architecture, Heritage

DOI: $\quad$ 10.17160/josha.3.5.228 


\title{
Heritage and Artistic Boon: Valuing Prizren Castle
}

\author{
Bujar Bajçinovci ${ }^{1}$, Kaltrina Thaçi ${ }^{* 2}$ \\ ${ }^{1}$ University of Prishtina, Faculty of Civil Engineering and Architecture, Kosovo. \\ ${ }^{2}$ Cultural Heritage without Borders, CHWB, Kosovo. \\ *2Email: kaltrinathaci@gmail.com, bujar.bajcinovci@uni-pr.edu
}

\begin{abstract}
There are a lot of disagreements of whether heritage assets and boon should be valued. A number of national and international accounting standards board's consider that bringing heritage assets on the balance sheet would improve the quality of the information reported. In order to include heritage assets in the balance sheet it is necessary to understand what they really represent. Hence, conceptually there is much cogitation among professionals about whether heritage assets should be indeed classified as assets, or whether they meet the rationale at all, given that a crucial part of the definition of an asset is that it should provide future wellbeing and benefit to the society. The research methods consist of empirical observation, focussing to the castle campus structure. In order to receive a clearer information's, exploring is made within heritage framework, shapes of architectural heritage structures, position of the castle regarding to the morphology of the city of Prizren. Prizren castle were investigated through literature review, Municipality documentations and old drawings. So, what is a heritage asset, and what in economically terms is defined as an asset? The methods of valuation, are quite difficult to be used as means for valuation of this site. This is mainly because no valuation of cultural heritage properties has been ever done in Kosovo. Surely, Prizren Castle should not be let, even actually its value is not known? On the other hand, we prefer that valuation methods can be modified and used, as a meaning for valuing the property? With the society moving towards greater energy consuming and environmental sustainability, Municipality and authorities must to reconsider to reuse the historic buildings before a new building has to be erected. Hence, we conclude that the valuations of heritage assets present unique challenges and for many of them, valuations are both possible and desirable, therefore valuing heritage assets can help in different means: lease renewal, rent review, taxation, management and conservation of heritage assets.
\end{abstract}

Keywords: Humanities, Art, Prizren Castle, Architecture, Heritage

\section{INTRODUCTION}

Prizren is the oldest city of Kosovo. The town is picturesque, with a castle, churches, mosques, numerous old houses and ancient Turkish baths. The cultural heritage of Prizren reflects a town with a large history. It was first mentioned as the Roman town of Theranda in Ptolemy's Geography in the $2^{\text {nd }}$ century $\mathrm{AD}$, and later as Petrizen in the $5^{\text {th }}$ century. In the beginning of the $13^{\text {th }}$ century, Prizren reached the culmination of its development, looking much like a medieval town in Western Europe with sophisticated 23 fortifications, a civitas (administrative and economic centre) and a castellum (castle town) [1] [6] [25]. In the center of the city above 
the foot hill, lies the Castle of Prizren. Due to its favourable geographic position, the use of the hilltop goes back to prehistoric times. It seems likely that the area of modern Prizren, at the foot of the hill and extending towards the plain, was also inhabited to some extent. The Fortress itself is located on a high hill on the south east site of the city of Prizren. It is situated close to the centre of the town and old town, where the Mehmet Pasha complex is which consists of a mosque, mausoleum and madrasa (school). The Fortress of Prizren, which was used as a fortification to protect the town of Prizren in times of war, has a direct link with the architecture of the old town and its thousand years of history [2] [6] [25].

"The Prizren castle contains an important part of ancient history of the city. Its topographic position, dominating the city, attractive landscape and the well thought architectural configuration, make this location with indisputable environmental, scientific, historical and touristic values. As an inherited asset from the Byzantine Empire, the castle lies on the southeast side of the city, built on a hill over 120 meters on the left side of the river Lumbardhi" [6] [25]. The primary function of the castle was a fortification that served to protect the population from attacks of various invaders, it was used exclusively as a fortress until 1912. Archaeological excavations conducted in 1969, 2004, and again 2009-2011, resulted in the discovery of the infrastructure, presented with walls reinforced with towers, casemates, mazes, depots and a range of objects within the structure. In terms of construction, the castle consists of three separate complexes, known as the Upper Town, Lower Town and Southern Town, while in terms of fortification during centuries, it belongs to different periods, such as the ancient period, the period of Byzantine rule, the medieval period and the period of the Ottoman Empire rule [6] [25].

According to the copy of plan, the site is owned by the Municipality of Prizren, and this site has statutory protection and is declared a protected cultural heritage asset. Excavation and conservation works are being undertaken by the Archaeological Institute of Kosovo. The Prizren Fortress is also used as a touristic attraction for the visitors as well as for film screening during the annual International Documentary and Short Film Festival. The position of the Fortress, dominating the city, very attractive natural landscape and architectural setting, makes it indisputably valuable [6] [25].

However, there are very little text resources about the Prizren castle. The name of the fortress was recorded for the first time by a Byzantine scholar, Procopius of Caesarea, in the work "De aedificiis" [3].

In this work, among refurbished fortifications in Dardania, "this castle is evidenced for the first time, so called Petrizen, the name holded nowadays by the city of Prizren" [4]. "The 
castle is built on natural stones. In ancient times it was used as a military stronghold. In its vicinity were discovered Neolithic era settlements and Illyrian pottery and weapons" (Krasniqi, 2002). During the Roman Empire, the original Illyrian town of Theranda was developed as a garrison near the castle. Before the Ottoman Empire, the castle was built as a fortification to protect the population from attacks of various invaders [5] [6] [25].

In most Rumelia cities occupied by Ottoman Empire, castles and fortresses of the Byzantine Empire after restorations were used as military garrisons [3]. During the Ottoman period the castle has been used consistently. During the rule of Mehmet Pasha (1809-36) clock tower was built in the castle, followed by a mosque in 1828. It is possible that the building was first erected in the second half of the $15^{\text {th }}$ century after the conquest of Prizren by the Ottomans in 1455 [6] [25].

After the conquest of Prizren, the Ottoman Empire concentrated all military forces in the city's castle. "After few interventions in the structure until the final withdrawal of the Ottoman Empire, the castle served as the main centre of military forces. In the castle, except special military units, also was space for military arsenal and later a prison was built. In the lower city, were southwestern and western casemates are connected, were placed ballsbombshells. One of these balls remaining from the Ottoman period still exists in the same place. In this part there used to be a weapon sanduk, with some weapons still existing in the same place. The castle had these units: infantry, cavalry, artillery and other Ottoman military units. According to data, in the castle barracks among others, the regiment II of Sultan II battalion also stayed. During the period when Prizren was the center of the vilayete, the castle had 2818 infantry soldiers, 836 cavalry soldier. Thus at that time the Prizren garrison had more soldiers than those in Nis, Skopje and Diber" [5] [6]. The Fortress covers an area of 1.6 ha (approx. 16.000 meters square). It is a heart shaped fortification which consists of three sub-complexes: Upper Fortress; (2) Lower Fortress and (3) Southern Fortress [2] [6] [25].

In 1798 the representative of Prizren, "Rustem Pasha with the help of his servants restored the castle again. Before Rustem Pasha, some representatives including those from Prizren had summer homes in the castle" [5]. By 1808, the fortress was in good condition and in the same year Emin Pasha Rotulli constructed the mosque. The renovation of the mosque was done by Mahmut Pasha Rotulli in 1828. During this time the Clock Tower was also constructed, the clock and the bell were brought from Smederevo [2]. According to Raif Virmica, "in 1831 Mahmut Pasha restored the casle and the mosque, which was demolished during the Austro-Ottoman war. The clock tower was also reconstructed at that time" [5] [25]. 
The fortress of Prizren was used exclusively as a military fortification until 1882, when some military premises were built in the western part of the town. The castle continued to be used as storage for guns, a jail and had also other secondary uses. Rapid deterioration of the fortress started after 1914. In 1938 a water reservoir was installed near the western covered corridor [2] [6] [25].

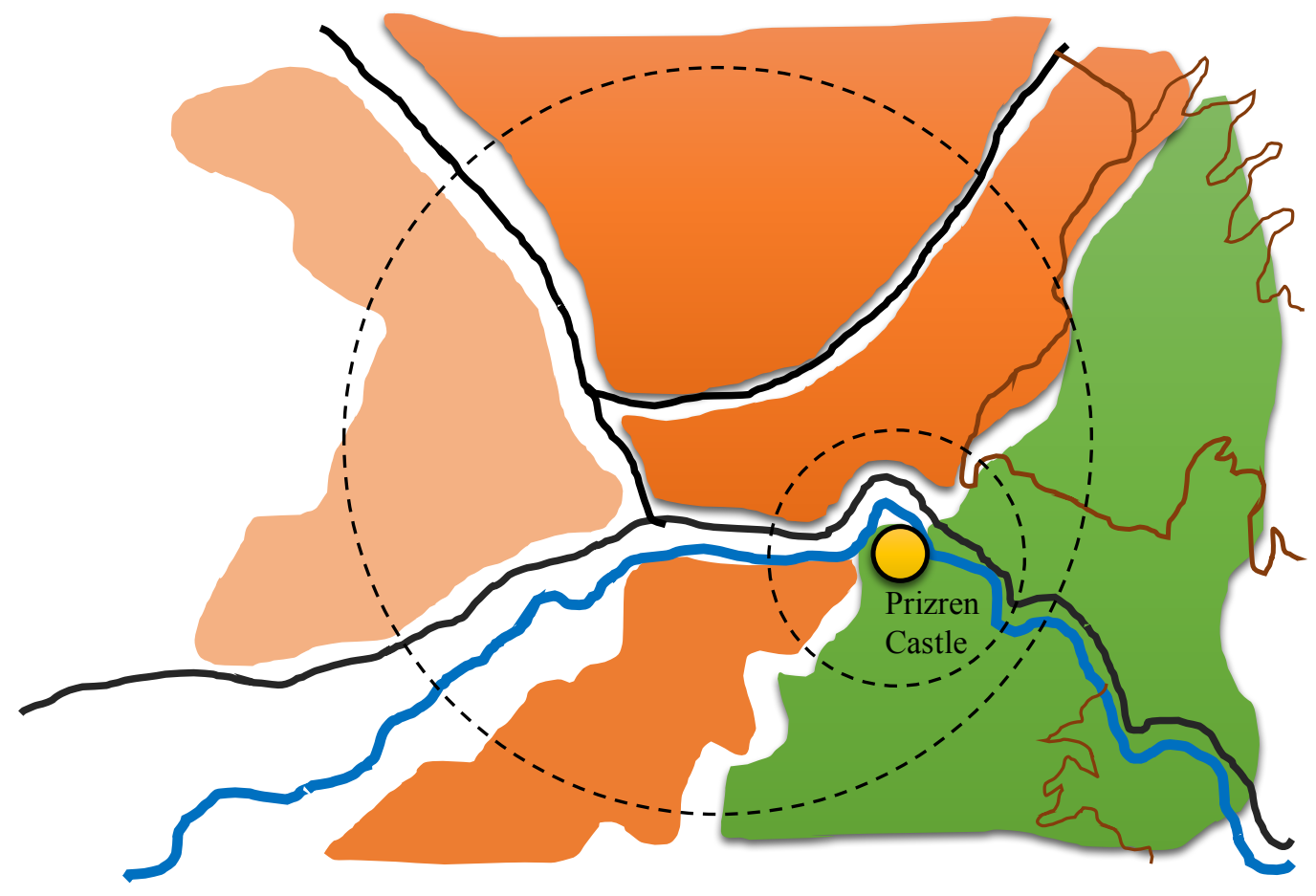

Figure 1. Urban morphology of Prizren. Castle silhouette is accented. Source: Authors, 2016.

Archaeological excavations conducted in 1969 and 2004 resulted in the discovery of the infrastructure, which is presented with walls (pinnacles) reinforced with towers, casamates, mazes, storages and a range of objects within the structure [6].

Continuation of archeological excavations conducted in 2004 and 2009/2011 revealed a prehistoric settlement from the late Bronze and early Iron period, which served as the first core of life in this country. Also for the first time these excavations revealed traces of architecture and evidence of datable material of Roman and late antiquity.

During the Ottoman period, "the castle expanded with fortification walls built and strengthened and enriched with new buildings such as the hammam, mosque and other buildings for military needs. Its last renovation was done in the third decade of the $19^{\text {th }}$ century, by the local family of Rotllaj" [6] [25]. 
In 2008-2010 some conservation-restoration works started as an emergency measure to prevent the degrading process of the castle [4]. Interventions in the castle undertaken during 50 's were focused mainly in geodesic recording [6].

In 1969 the first archaeological excavations were done. At the same time the adaption plan of the castle was elaborated. Archaeological excavations have continued in 2004, 2009-ong. [25].

Fieldwork already conducted:

- $\quad$ Restoration - conservation works in 1963 and 1964 [2].

- Archaeological excavation and conservation in 1969, by IPCM Serbia and IPCM Kosovo [2].

- From 1969 to 1999 minor interventions have been conducted on bastions and certain parts of the fortress in order to prevent its further devastation. During that period global works for the protection and parts of the fortress haven't been undertaken [2].

- A path has been laid from St. Trinity church up to the fortress entrance, together with illumination by electricity, in 2003 [2].

- Archaeological excavations and the partial cleansing of the vegetation in 2004 [2].

- Since 2009, archaeological excavations and conservation of structures are financed by the Ministry of Culture, Youth and Sport and implemented by the Kosovo Archaeological Institute" [2] [6] [25].

From past excavations in the fortress, many interventions carried out in different time periods were noticed. These "interventions were mostly conducted in the $16^{\text {th }}$ and $17^{\text {th }}$ century. In the $16^{\text {th }}$ century, the Ottoman Empire after the interventions that separate the upper town and lower town of the castle, built two rectangular towers. While in the $17^{\text {th }}$ century the interventions have largely influenced the growth and change of the overall shape of the castle. In the east side of the castle was built a tunnel, while in the south side of the upper city, the lower city was formed. Among these interventions are the reinforcements of casamates holders between the upper and the lower city" [6]. Also on the north, northwest and northeast side other casamates were built. One of the casemate built on the west side of the lower city was restored after being quite damaged. During the 1969 excavations, were discovered traces of the $19^{\text {th }}$ century mosque. It was also revealed that another mosque dating from the $16^{\text {th }}$ century existed at the same location. Until today the most preserved parts of the castle are those restored during the $16^{\text {th }}$ and $17^{\text {th }}$ 
century. In the $19^{\text {th }}$ century, special rooms were built within the casametes. These rooms were used as prisons or might have been built only to resist destruction [5] [6] [25].

\section{MATERIALS and METHODS}

The study presented in this paper explored the Prizren urban composition structure, with accent on the Prizrens's castle, and humanities heritage assets. The research methods consist of empirical observation, focussing to the castle campus structure. In order to receive a clearer information's, exploring is made within heritage framework, shapes of architectural heritage structures, position of the castle regarding to the morphology of the city of Prizren. Prizren castle were investigated through literature review, Municipality documentations and old drawings. Most documentation contains old photos, pictures of the urban composition of castle campus, regarding to the city urban spatial regulation. The collected documents include maps, drawings, history observations, government documentations, environmental features and attributes of space. The supplementary data for this study is based on the analysis of the Municipality of Prizren archives, and researches within the Kosovo Institute of Archaeology.

\section{Protection of the heritage site}

During the period 1948-1999 the fortress was protected at national level. It was classified as a "first level" monument. Prizren Castle is a protected archaeological site since 1967. The site is in the List of Cultural Heritage under Temporary Protection of the Ministry of Culture, Youth and Sports. (Decision number 1585/48, MCYS, 2014) This site is protected by the Law on Cultural Heritage (No. 02/L-88), Law on Special Protective Zones (No. 03/L-039) and Law on Historic Center of Prizren (No. 04/L-066) [6] [25].

At the local level, in December 2008 the Municipality of Prizren adopted Prizren Historic Area Conservation and Development Plan (2008), which serves as a regulatory plan for the historic area of Prizren. Prizren Castle is in the Zone IV of Potkaljaja- Preserving the urban traditional model. Restoration of the Church of St. Saviour, Theological School and the City Castle [2] [6] [25].

\section{Condition of the heritage boon}

The castle is constantly exposed to climate conditions: "humidity, freezing temperatures, heat and abundant vegetation, which by their complexity systematically harm the castle. The other destructive factor is the lack of protection and the free and uncontrolled movement of visitors over the castle walls, which harms the peripheral walls and the walls of 
the other objects within the interior of the castle. The castle is going under a number of threats actually" [6].

An eventual threat might arise from developers wishing to build a local ski link and big asphalt road near the site. There was also a proposal for building a modern hotel on the site in the last two decades. "Lack of a management plan will lead to unplanned buildings in the structure. There is a lack of instructions/ signs for visitors, and no sign showing that the site is a protected asset. There is an emerging need for restrictions as to where people can move on the site and a need for the wall edges to be protected. Approach through the route toward the castle is not adequate. There is lack of a parking lot and no area for the exclusive use of disabled people" [2] [4] [6] [25].

\section{The connotation of the site}

"Prizren's Fortress is one of the most ancient forts in Kosovo and is considered to have extraordinary archaeological, architectural, historical and cultural heritage value for the country, in particular, and South-East Europe in general. Located on the south-east side of Prizren, it is considered to be the city's symbol and an important element in Kosovo's cultural identity. Built on a high hill, in a picturesque environment, and having an extraordinary strategic location, the Fortress dominates the town as well as the impressive, deep Lumbardhi/Bistrica valley and the big Dukagjini area" [6]. Its historical values arise from the fact that it was the first cell of the ancient city of Prizren, with a dominant position over the city, in a very picturesque countryside. As such, the castle became a symbol of the city, as well as of the region. There is cultural stratification since the prehistoric period. Parts of its architecture belong to an early Byzantine period, but the Ottoman character predominates. According to historical sources, some objects of Slavic architecture, might have existed. The Ottoman military architecture is individualized by the general concept of a harmonious building conception, using the whole terrain space and the dominant position of the hill. The Castle was built using local materials with traditional techniques. The variety of stones used in the structure increase the Castle's grandiosity [2] [6] [25].

\section{The preservation of the site}

The project for the preservation of Prizren Castle is implemented by Cultural Heritage without Borders ( $\mathrm{CHwB})$, responsible for the interpretation, adaptation and management plan of the site as well as the Archaeological Institute of Kosovo, responsible for the excavation and 
conservation of the castle structures. The length of the project is 36 months, starting from 20152017, (CHwB) [6].

"The working group of the project composed of representatives of $\mathrm{CHwB}$, the Archaeological Institute of Kosovo, Kosovo Council for Cultural Heritage, Council on Historic Centre of Prizren, the Ministry of Culture, Youth and Sport, Kosovo Institute for the Protection of Monuments, the Ministry of Environment and Spatial Planning, the Municipality of Prizren, NGOs and independent professionals have started the first activities for the implementation of the project" [6] [25].

The "memorandum of understanding for the preservation of Prizren Castle" was signed on the 25th of September 2014, between CHwB Kosovo, Kosovo Archaeological Institute, Ministry of Culture, Youth and Sport and the US Embassy in Pristina, which is also funding the project through the Ambassadors Fund for Cultural Heritage [6] [25].

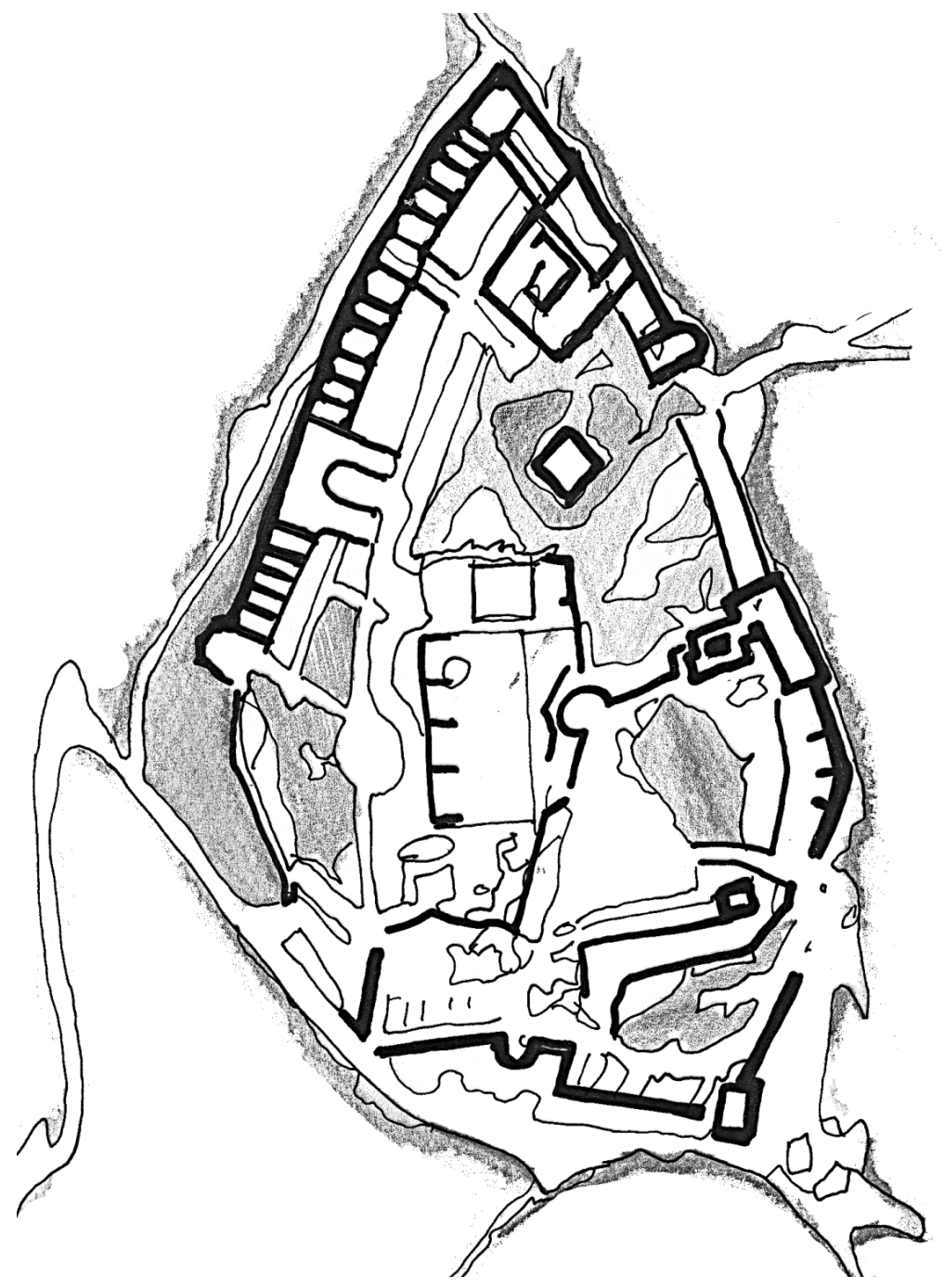

Figure 2. Composition of campus structure, castle in Prizren. Source: Authors, 2016. 


\section{RESULTS and DISCUSSION}

"The sustainable management of cultural heritage at the service of development bears at least two important dimensions, that of longevity and that of economic, environmental and social viability. Thus in the first instance, the physical aspects of cultural heritage (the brick and mortar of historical buildings, the objects of material culture) are valued and their continued existence in good condition represents a form of sustainability of heritage management... Secondly, no management of cultural heritage is sustainable unless it is economically, environmentally and socially viable" [7].

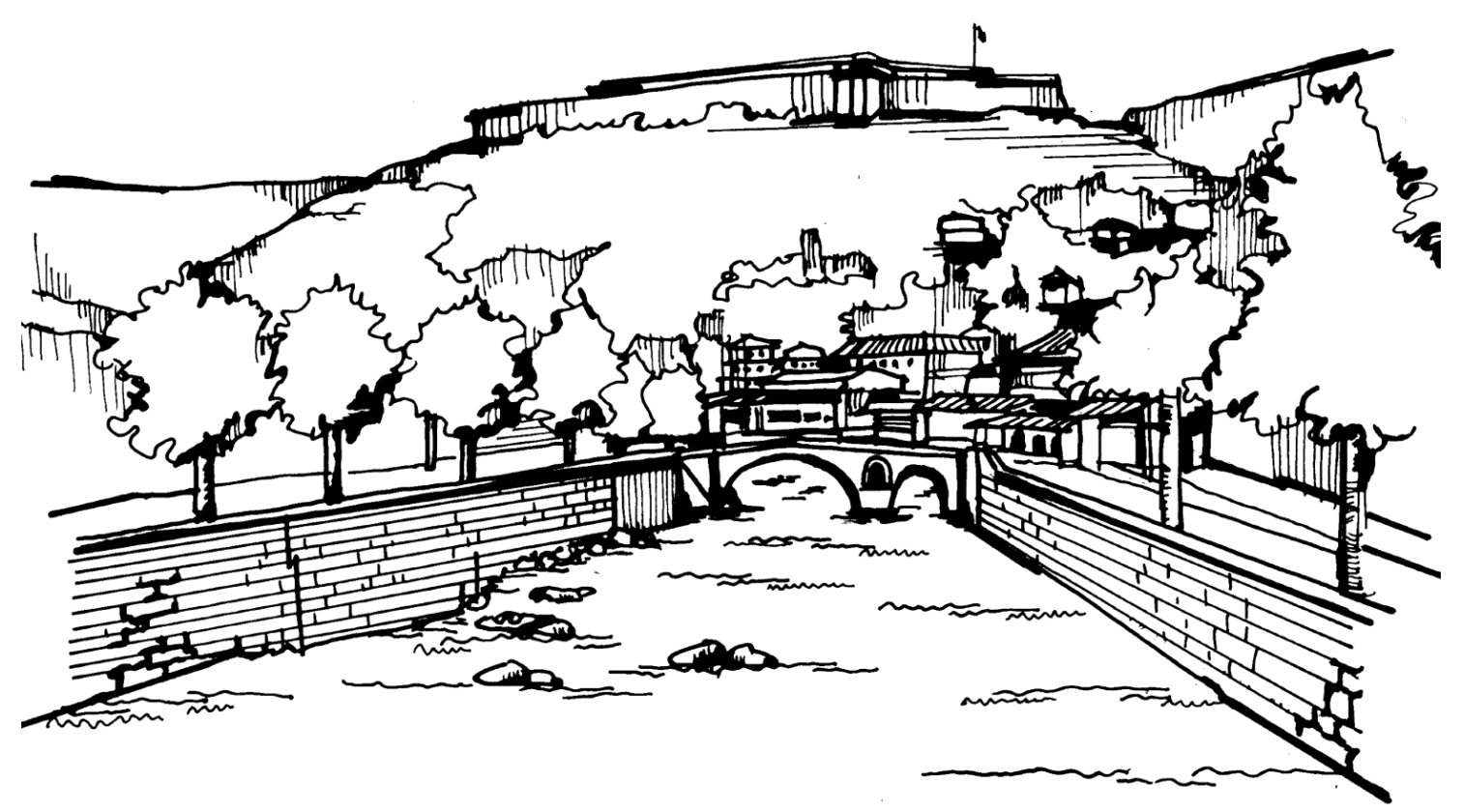

Figure 3. Urban composition and visuality of castle in Prizren. Source: Authors, 2016.

\section{Reminiscence and heritage boon of the site}

"The inclusion of heritage assets in the balance sheet could provide the opportunity for governments or other bodies that hold them to obtain useful information about their nature and potential in order to facilitate the achievement of objectives for decision-making and performance measurement" [8].

"Much of the debate in the literature comes from the Australian and New Zealand cases, where governments were early adopters of NPM techniques, and have required heritage assets to be shown on balance sheet as part of property, plant and equipment. Some commentators 
agree with the standard setters that heritage assets are considered assets because they assist the entities to achieve their objectives and so they can be included on the balance sheet" [9].

Even if they are not able to generate direct future economic benefits, these benefits accrue from their ability on satisfying human wants and needs. "The majority of academics who don't agree with the idea of valuing heritage assets argue that they cannot properly be described as financial assets and do not satisfy the criteria for recognition as an asset... Heritage assets "are not assets, either in conventional accounting terms or in commercial or common-sense terms" [10] [22].

Moreover, they argue that "heritage assets have cultural, historical and scientific value that cannot be translated into financial terms". Hence, they are "items held in trust by entities". Repositories of collections are "not commercial enterprises": "Their business is to be and to hold, not to do business and, as a consequence, they have non-commercial objectives" [11].

Hence, Barton 2000, argues that heritage assets are mainly managed by governments as a trustee for the benefit of society. They therefore do not belong to governments but to the community: "They are the people's assets managed and controlled by government on behalf of its citizens". According to, Barton 2000, as trustee assets they must be represented in a separate budget compared to other assets that are used for operational purposes [11].

Similar views are also held by, Pallot 1990 [12], and Mautz 1998 [13], who respectively classify such assets as "community assets and facilities assets". Mautz's earlier work,1988, took the view "that heritage assets should not be considered assets because they are not able to generate positive cash flow". He argues that "heritage assets have a use to the external community, rather than being represented by an economic use through the potential of a future sale. As they are vital to the pursuit of social goals to which the public entities aspire, they will not usually be sold“ [13] [22].

Carnegie and Wolnizer, 1995 [9], have built on this view and argue that given their nature, heritage assets are able to absorb wealth but not to generate it in financial terms: "whilst revenue income is low or zero, resources need to be spent maintaining and conserving, thus leading to overall net negative cash flow. As a consequence, it would be more appropriate to classify them as liabilities, or alternatively to call them facilities and show them separately. Facilities encompass all those heritage assets that are acquired principally to facilitate transferring resources (as social benefits) to the community" [10] [22].

These "considerations are valid both for the public and not-for profit sector but including heritage assets in the balance sheet, whether as part of property, plant and equipment, 
as required by international standards, or in a separate class as suggested by academics, raises issues about their recognition and valuation", as noted by Christiaens, 2004 [14].

And also their disclosure [15], on the other hand, "there have been so many debates if actually putting a value on heritage assets gives an opportunity to obtain future economic benefits, if heritage assets have historic value which shouldn't be translated into economic value and if heritage assets should be represented in a separate budget. The question is whether these arguments come as a result that many people believe that heritage belongs to social life thus it shouldn't be sold nor economically valued. Some people may ask why we bother to value our heritage at all: surely our heritage is beyond monetary value? But life is not as simple as that, the built heritage does have to be valued, and the methods by which society places value, and the accuracy of these methods, have over the past twenty years become increasingly important when decisions affect the future of our historic heritages" [16] [22] [25].

\section{Approaches of accounting for heritage assets}

"The valuation methodology of heritage assets can be split into traditional market valuation methods, which are used for majority of heritage assets, and the non-market valuation methods, which attempt to place a value on the non-functional heritage assets" [16] [17] [22].

\section{Market value valuation methods}

"The most common methods are the comparable and investment methods. The comparable method analyses recent transactions of similar properties in the same location. It applies a rate per square metre to the property to be valued, having made adjustments for location, condition and so on. It is a reasonable and accurate method for commercial and residential valuations, but it more complex when applied to historic houses. In some places it is impossible to use this method, for example in the Royal Crescent in Bath, none of historic buildings is identical, and thus the architectural style, attractiveness, history, repair and possible maintenance complicate the approach. The investment method is where an income stream is capitalised at a yield determined by the market" [16].

"Careful analysis of comparable transactions is required to judge the income flow projection. This method applies mainly to commercial properties such as offices, shops, factories and warehouses. Another valuation technique that applies to businesses, especially hotels, is the going concern approach. Some historic hotels and large country houses converted 
to hotels can generate a 'heritage premium', and a higher room rental can be achieved because of the historical ambience and architectural style of the property" [16].

"Another valuation method is the Depreciated Replacement Cost, which is not normally considered appropriate for heritage assets" [17].

\section{Non-market value valuation methods}

"The contingent valuation method (CVM): directly questions consumers on their stated willingness to pay for example an environmental improvement or their willingness to accept compensation for a fall in the quality of the environment" [16].

"The hedonic pricing method (HPM): was developed by Rosen, 1974, and is similar to the traditional comparable method. It is the most theoretically rigorous valuation method, which aims to determine the relationship between the attributes of a good and its price. The basis of this method is that any differentiated product unit can be viewed as a bundle of characteristics, each with its own implicit price. In the case of housing, for example, the characteristics may be structural, such as number of bedrooms, size of plot, presence or absence of garage, and can range through to environmental matters, noise levels, presence of views and crime rate" [16] [18].

"The travel cost method (TCM): developed by Clawson and Knetsch, 1966, is a simpler method than HPM, because it is based on the premise that the cost of travel to recreational sites can be used as a measure of visitors' willingness to pay“ [16] [18]. Loughborough University developed another system that helps to assess the construction projects' value. "It is called Managing Value Deliver in Design (VALiD) and is specially designed to help stakeholders understand one another during team formation and provide a comprehensive view on value" [19].

"The market value of a property is used by local planning authorities and English Heritage when considering applications for enabling development. Both English Heritage and Heritage Lottery Fund use market valuations when assessing certain types of grant assistance, as do leading bodies when valuing heritage properties for lending purposes" [21] [23].

On the other hand, RICS and Kingston University conclude in their report that "many heritage assets are not capable of being valued to Market Value, using conventional techniques. For such assets, the use of a cost approach is also inappropriate. Accordingly, it puts forward for debate some possible alternative methodologies that could be considered appropriate to provide owners and their stakeholders with better information as to the worth of their assets. 
The market value approach is recommended for valuations of portable property, taking due account of issues of lotting and location connectivity" [17].

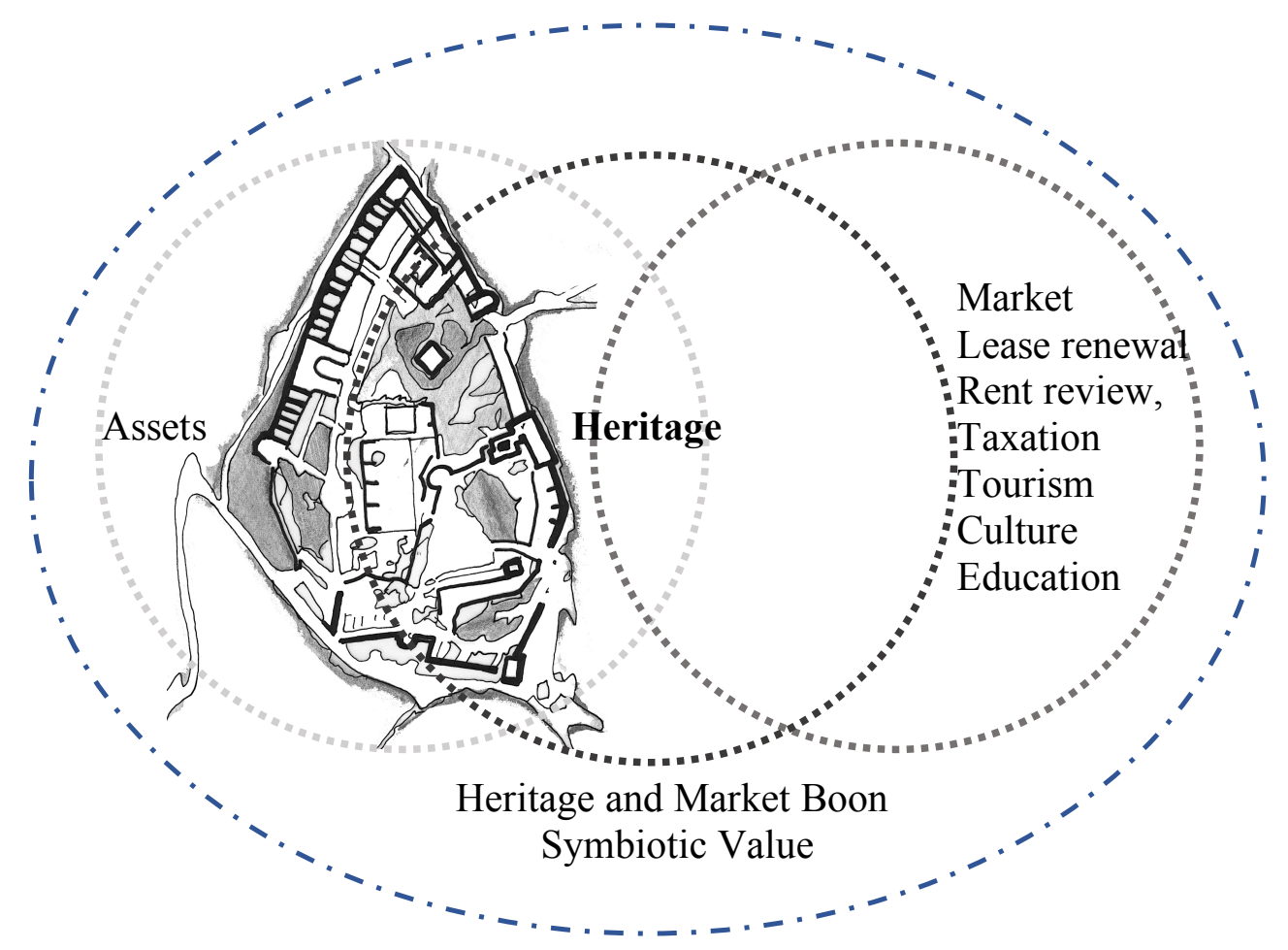

Figure 4. Preferred symbiotic role: Heritage and Market boon. Source: Authors, 2016.

"Alternative Approaches: Contingent valuation or contingent choice methods could also be used in this case. While they might produce more precise estimates of values for specific characteristics of the site, and also could capture non-use values, they would be considerably more complicated and expensive to apply“ [24].

Hence, conceptually there is much cogitation among professionals about whether heritage assets should be certainly classified as assets, or whether they meet the rationale at all, given that a crucial part of the definition of an asset is that it should provide future wellbeing and benefit to the society.

\section{CONCLUSIONS}

The fortress is a site with a great local social impact being the main attraction in the town of Prizren. There are no commercial facilities in the fortress hence the site has not contributed to the development of local commerce. Expectations are high on the role the fortress can play in the sustainable development of the town of Prizren. Hence, these expectations have not been 
met and in order to meet them, a lot of efforts are required to make the fortress a self-sustaining site. With such an attractive position overlooking the 'cultural capital' of Kosovo, the fortress is frequently visited by the local community and international visitors. It has great potential for further development of cultural tourism, recreation, and cultural activities. When conserved and adapted for new use, the new function will be designed with the committee and public consultations, and a management plan has to be drafted and implemented. Before drafting the document, a managing body should be established, being it a governmental organization, nongovernmental organization, private companies or Public-Private. However, if a castle would be managed by a private company, it should somehow be valued, so that its rent could be calculated properly as well as its income generating. The methods of valuation, stated above are quite difficult to be used as means for valuation of this site. This is mainly because no valuation of cultural heritage properties has been ever done in Kosovo, and for example, the comparable method cannot be considered. Surely, Prizren Castle should not be let, even actually its value is not known? On the other hand, we prefer that these methods can be modified and used, as a meaning for valuing the property? With the society moving towards greater energy consuming and environmental sustainability, Municipality and authorities must to reconsider to reuse the historic buildings before a new building has to be erected. Hence, we conclude that the valuations of heritage assets present unique challenges and for many of them, valuations are both possible and desirable, therefore valuing heritage assets can help in different means: lease renewal, rent review, taxation, management and conservation of heritage assets.

\section{References}

[1] Thaci, K. (2011) The interaction between inscribed and potential World Heritage Sites and new developments in the same environment. Unpublished dissertation. London: Kingston University.

[2] European Commission/ Council of Europe (2009) Preliminary Technical Assesment of the Architectural and Archaeological Heritage in South East Europe. Prizren Fortress (Kalaja) Prizren.

[3] Procopius, c. AD. 500, http://research.omicsgroup.org/index.php/Procopius, [Accesed: September 2016.

[4] Ministry of Culture, Youth and Sport (2015) Cultural Heritage Database. Prizren Castle.

[5] Virmiça, R. (1999) Kosova'da Osmanli Mimari Eserleri, Ankara.

[6] CHwB (2011) Conservation and Development Plan for the Historic Zone of Prizren. The project for the preservation of Prizren Castle, 2015. Kosovo: CHwB.

[7] UNESCO, Towards a UNESCO culture and development indicators suite.

http://www.unesco.org/fileadmin/MULTIMEDIA/HQ/CLT/creativity/pdf/culture and develo pment indicators/Dimension\%203\%20Heritage.pdf [Accesed; September, 2016].

[8] Barton, A. (2005) The conceptual arguments concerning accounting for public heritage assets: a note. Accounting, Auditing \& Accountability Journal, Vol. 18 No. 3. 
[9] Micallef, F. and Peirson, G. (1997) Financial reporting of cultural, heritage and scientific and community collections. Australian Accounting Review, Vol. 7, NO 1.

[10] Carnegie, G.D. and Wolnizer, P. (1999) Unravelling the Rhetoric about the Financial Reporting of Public Collections as Assets, Australian Accounting Review, Vol.9, No1, pp. 16-21.

[11] Barton, A. (2000) Accounting for public heritage facilities - assets or liabilities of the government? Accounting, Auditing \& Accountability Journal, Vol. 13 No. 2.

[12] Pallott, J. (1990) The nature of public assets: A response to Mautz. Accounting Horizons, June.

[13] Mautz, R.K. (1988) Monuments, Mistakes, and Opportunities. Accounting Horizons, June.

[14] Christaens, J. (2004) Capital Assets in Governmental Accounting Reforms: Comparing Flemish Technical Issues with International Standards. European Accounting Review, Vol. 13, No. 4.

[15] Stafford, A. \& Lacerra, A. (2009) Accounting for the past: the challenges for UK public benefit entities in accounting for heritage assets. A paper for presentation at the BAA Northern Accounting Group Conference, Manchester Metropolitan University. UK: Manchester Business School.

[16] Forsyth, M. (2007) Understanding historic building conservation. Oxford: Blackwell.

[17] Kingston University \& RICS (2009) Valuing Heritage Assets. Final report of a research project: Examining the case for the valuation of heritage assets. London: RICS.

[18] Rosen, S. (1974) Hedonic prices and implicit markets. Journal of Political Economy 82. P.34-55.

[19] Clawson, J. \& Knetsch, M. (1966) Economics of outdoor recreation. Baltimore: Johns Hopkins Press.

[20] Thomson, D. et.al. (2003). Managing value and quality in design. Building research and information 31, 5. P. 334-345. http://www.valueindesign.com/

[21] Boniface, S. (1998) Mortgage valuations on historic buildings. The building conservation directory. Tisbury: Cathedral Communications.

[22] Aversano, N., Ferrone, C, 2012. The accounting problem of heritage assets, Advanced Research in Scientific Areas 2012. International Virtual Conference.

[23] Whimster, Associates, Enabling development and the conservation of significant places, English Heritage 2008

[24] Travel Cost Method, http://www.ecosystemvaluation.org/travel costs.htm [Accessed: September, 2016].

[25] Thaci, K., Bajçinovci, B,. Aliu, R. 2015. ${ }^{\text {rd }}$ International conference, CICOP BiH, The Importance of Place. CICOPBH, Sarajevo Vol. 3 No. 1, 2015.

[26] Porter, S. (2004) An examination of measurement methods for valuing heritage assets using a tourism perspective. Qualitative Research in Accounting \& Management, Vol. 1 No. 2.

[27] FRAB (2001) FRAB Fourth Report 2000-2001.

[28] ASB-Accounting Standards Board (2009) FRS 3042 Heritage Assets. London. 